\title{
EKSTRAKSI INFORMASI UNTUK NOVEL
}

\author{
Arbi Insani ${ }^{1}$, Nelly Indriani Widiastuti ${ }^{2}$ \\ 1,2 Teknik Informatika - Universitas Komputer Indonesia \\ Jalan Dipatiukur 112-116 Bandung \\ E-mail : ${ }^{1}$ arbi_benai@yahoo.com, ${ }^{2}$ nelly.indriani@email.unikom.ac.id
}

\begin{abstract}
ABSTRAK
Informasi dalam bentuk digital menjadi salah satu alternatif untuk mendapatkan informasi yang akurat dan cepat. Pada umumnya setiap perpustakaan melakukan pendataan informasi dan identitas suatu dokumen dilakukan dengan cara mengisi data kedalam sistem, masalah yang dihadapi oleh pustakawan adalah setiap kurun waktu ke waktu dokumen setiap tahunnya bertambah dan jumlahnya yang banyak mengakibatkan dalam melakukan pendataan informasi novel banyak terjadi kesalahan dan membutuhkan waktu yang lama dalam pendataan novel. Dalam penelitian ini di bangun suatu sistem agar dalam pengerjaan pendataan informasi dapat dilakukan secara otomatis oleh sistem yaitu dengan cara mengekstraksi informasi tersebut secara mudah, cepat dan menghasilkan data informasi yang benar. Ekstraksi informasi yang digunakan dalam penelitian ini menggunakan metode berbasis aturan atau disebut rule-based. Metode ini merupakan suatu metode yang menggunakan aturan berdasarkan fakta dari data yang dianalisis. Hasil penelitian ini menunjukkan hasil setelah dilakukan pengujian akurasi menggunakan 50 buku berupa novel. Hasil yang ditunjukkan sangat baik. Hal ini berarti ekstraksi informasi pada penelitian ini dapat digunakan untuk mengekstrak identitas data pada novel.
\end{abstract}

Kata Kunci : Rule-based, ekstraksi Informasi, novel.

\section{PENDAHULUAN}

Proses perkembangan teknologi informasi dan komunikasi saat ini begitu pesat dan meningkat, terutama informasi dalam bentuk novel, jurnal, majalah, artikel, koran, dan berita. Informasi dalam bentuk digital menjadi salah satu alternatif untuk mendapatkan informasi yang akurat dan cepat. Novel adalah karangan yang panjang dan berbentuk prosa dan mengandung rangkaian suatu cerita kehidupan seseorang dengan orang lain maupun cerita fiksi yang ada di sekelilingnya dengan menonjolkan watak dan sifat setiap pelaku [1]. Perkembangan novel selalu bertambah setiap waktunya seperti contoh novel manusia setangah salmon, 7 rahasia shope dan lain sebagainya. Pada umumnya setiap perpustakaan melakukan pendataan informasi dan identitas suatu dokumen novel dilakukan dengan cara mengisi data kedalam sistem. Masalah yang dihadapi oleh pustakawan adalah dari waktu ke waktu dokumen setiap tahunnya bertambah. Jumlah yang banyak mengakibatkan terjadi banyak kesalahan dalam melakukan pendataan informasi novel dan membutuhkan waktu yang lama.

Proses ekstraksi informasi (Information Extraction atau IE) adalah sebuah proses untuk menemukan informasi terstruktur dari dokumen tidak terstruktur atau semi terstruktur. Adapun data yang terstruktur adalah data yang telah terorganisir sehingga mudah dalam suatu pencarian data sedangkan tidak terstruktur adalah data yang belum terorganisir [2]. Contoh dari ekstraksi informasi adalah mengekstraksi iklan Koran, berita, karya ilmiah dan lain sebagainya sesuai penelitian sebelumnya oleh Ramón yaitu menggunakan ekstraksi informasi untuk mengklasifikasikan iklan koran [3]. Penelitian yang dilakukan Riaddy dkk. membahas ekstraksi informasi untuk makalah ilmiah menggunakan pendekatan supervised learning [4]. Pada penelitian lain menyimpulkan bahwa ektraksi informasi pada dokumen LHP (Laporan Hasil Pemeriksaan) dapat dilakukan dengan menggunakan rule-based classification dengan akurasi data latih sebesar 98,27\% dan akurasi data uji sebesar $89,77 \%$ [5]. Penelitian oleh Muhammad Habibi yang melakukan ekstraksi informasi untuk evaluasi pemahaman fisika kinematika bisa dilakukan dengan metode rule-based dengan hasil akurasi sistem yang telah dibangun menghasilkan nilai $\mathrm{F}$ - Measure berkisar antar 90.6\% - 95.4\% [6]. Pada penelitian oleh M. Karibun menyimpulkan bahwa penerapan metode rule-based dengan unsupervised learning untuk pelabelan dokumen berbahasa Indonesia dapat mengenali $97,85 \%$ token [7]

Berdasarkan uraian tersebut maka dalam penelitian ini bertujuan untuk membangun sebuah 
sistem ekstraksi informasi dokumen teks novel dengan menggunakan metode rule-base agar dapat dalam pendataan informasi menghasilkan pendataan yang akurat, cepat, mudah dan tidak membutuhkan waktu yang lama. Dengan adanya sistem tersebut diharapkan akan lebih mudah dan cepat dalam pendataan informasi novel.

\section{ISI PENELITIAN}

\subsection{Metode Penelitian}

Pada penelitian ini sistem dibangun menggunakan metode rule-base untuk ekstraksi informasi dokumen. Dimana rule-base dikenal juga dengan sebutan pendekatan hand-crafting atau Knowledge engineering. Disebut pendekatan rule base karena rule-base ini memanfaatkan keahlian manusia (human expert) untuk membuat suatu aturan-aturan (rules) secara manual melalui proses pemahaman manuasi itu sendiri. Human expert atau pakar dituntut untuk bisa memahami domain sistem [8].

Adapun gambaran umum analisis sistem yang akan di bangun pada ekstraksi informasi dokumen teks ini dapat dilihat pada gambar 1 .

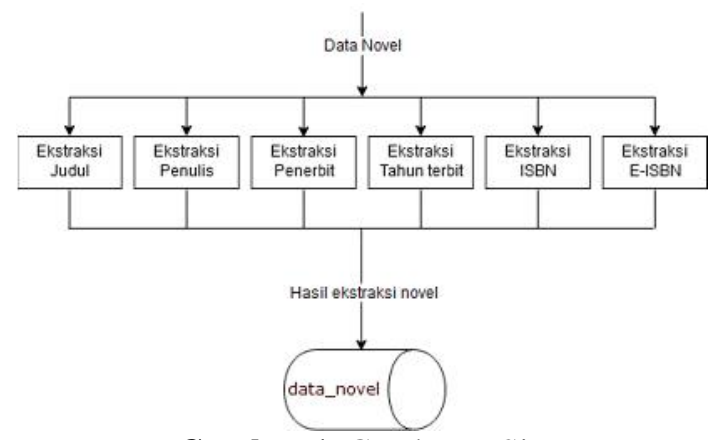

Gambar 1. Gambaran Sistem

Gambaran Tahapan Sistem akan dijelaskan sebagai berikut ini.

1. Pada tahap awal pengguna memasukan file teks yang merupakan novel yang berformat .txt ke dalam sistem

2. Selanjutnya sistem akan mengekstraksi informasi yaitu judul, penulis, penerbit, tahun terbit, ISBN, E-ISBN dari data novel tersebut. Proses ini dilakukan dengan mencari kata kunci yang dapat dijadikan acuan pembentukan aturan.

3. Tahap terakhir informasi dari data akan disimpan ke dalam tabel.

\subsection{Analisi Data Masukan}

Analisis data masukan pada penelitian ini menggunakan data novel yang berformat jpg yang di konversi ke .txt. menggunakan aplikasi OCR atau Optical Character Recognition. OCR adalah aplikasi yang berfungsi untuk men-scan gambar kemudian dikonversi menjadikan text dan aplikasi ini juga dapat menjadi support /aplikasi tambahan untuk scanner. Dengan adanya OCR, Image yang bertulisan tangan, tulisan mesin ketik atau computer text, dapat dimanipulasi kedalam bentuk format yang berbeda [9].

Pada penelitian ini analisis berfokus pada pencarian kata kunci dan aturan yang akan digunakan untuk mengekstraksi informasi data novel. Berikut adalah data novel sebelum di konversi ke .txt dilihat pada gambar 2 berikut.

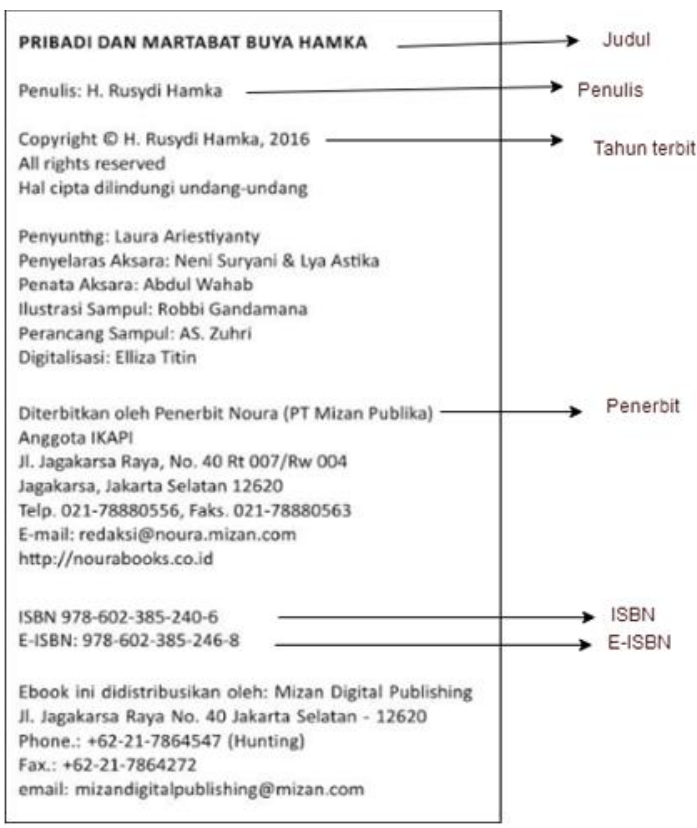

Gambar 2. data novel

Pada gambar 2 adalah contoh data novel yang berjudul "PRIBADI DAN MARTABAT BUYA HAMKA" dan akan diambil 6 data ekstraksi informasi yaitu :

1. Judul novel yaitu "PRIBADI DAN MARTABAT BUYA HAMKA" yang muncul pada awal data novel sehingga hal ini dapat menjadi aturan dalam pengambilan ekstraksi informasi.

2. Penulis yaitu "H. Rusydi Hamka". Pengambilan penulis di peroleh dari kata kunci dikarenakan sebelum kata H. Rusydi Hamka terdapat kata kunci yaitu penulis

3. Tahun terbit yaitu "2016" merupakan tahun terbit dari novel. Pengambilan tahun terbit menggunakan rentang nilai angka $2001-2025$.

4. Penerbit yaitu "Noura (PT Mizan Publika)" merupakan penerbit dari novel untuk pengambilan penerbit menggunakan kata kunci dikarenakan sebelum kata noura terdapat kata penerbit.

5. Nomor ISBN yaitu "973-602-385-240-6" merupakan ISBN novel. Pengambilan ekstraksi menggunakan kata kunci karena sebelum 973602-385-240-6 terdapat kata ISBN. 
6. Nomor e-ISBN yaitu "978-602-385-246-8" merupakan kode e-ISBN novel. Pengambilan ekstraksi menggunakan kata kunci karena sebelum 978-602-385-246-8 terdapat kata eISBN

\subsection{Analisis Pembentukan Aturan dan Kata \\ Kunci}

Kata kunci adalah suatu kata yang menjadi acuan suatu dari data [10]. Kata kunci dapat digunakan sebagai acuan dalam pembentukan aturan untuk pengambilan suatu data dalam proses ekstraksi informasi pada novel. Selain kata kunci, aturan tata letak kata juga dapat digunakan sebagai salah satu acuan dalam pebentukan aturan. Berdasarkan datadata yang diamati yaitu dengan mengambil kata kunci dan tata letak, sebagai dilihat pada tabel 1

Tabel 1. Aturan dan kata kunci

\begin{tabular}{|c|c|c|}
\hline Nama & Kata Kunci & Aturan \\
\hline Judul & & $\begin{array}{ll}\text { - } & \text { baris pertama } \\
& \text { dari data novel }\end{array}$ \\
\hline Penulis & $\begin{array}{ll}\text { - } & \text { Penulis } \\
\text { - } & \text { penulis } \\
\text { - } & \text { Karya } \\
\text { - } & \text { karya }\end{array}$ & $\begin{array}{l}\text { - Jika kata setelah } \\
\text { "Penulis", } \\
\text { "penulis", } \\
\text { "Karya", } \\
\text { "karya" maka } \\
\text { diambil sebagai } \\
\text { penulis } \\
\text { - Jika kata setelah } \\
\text { kata kunci } \\
\text { kosong maka } \\
\text { diambil baris } \\
\text { berikutnya } \\
\text { setelah kata } \\
\text { kunci yang } \\
\text { ditemukan }\end{array}$ \\
\hline $\begin{array}{l}\text { Tahun } \\
\text { terbit }\end{array}$ & $\begin{array}{l}2000 \\
\text { sampai } \\
2025\end{array}$ & $\begin{array}{ll}\text { Jika ditemukan } \\
\text { rentang angka } \\
\text { tahun } 2000- \\
2025 \text { maka di } \\
\text { ambil sebagai } \\
\text { tahun terbit. } \\
-\quad \text { Menggunakan } \\
\text { aturan rentang } \\
\text { angka dan yang } \\
\text { paling awal di } \\
\text { temukan pada } \\
\text { data novel }\end{array}$ \\
\hline Penerbit & $\begin{array}{ll}- & \text { Penerbit } \\
- & \text { penerbit } \\
- & \text { diterbit- } \\
& \text { kan } \\
- & \text { Diterbit- } \\
& \text { kan } \\
- & \text { Redaksi } \\
- & \text { redaksi }\end{array}$ & $\begin{array}{l}\text { mengambil kata } \\
\text { setelah kata } \\
\text { kunci yaitu } \\
\text { "Penerbit", } \\
\text { "penerbit", } \\
\text { "Diterbitkan", } \\
\text { "diterbitkan", } \\
\text { "Redaksi", atau } \\
\text { "redaksi" maka } \\
\text { di ambil sebagai } \\
\text { penerbit. } \\
\end{array}$ \\
\hline
\end{tabular}

\begin{tabular}{|c|c|c|}
\hline & & $\begin{array}{l}\text { Jika kata setelah } \\
\text { kata kunci } \\
\text { kosong maka } \\
\text { diambil baris } \\
\text { berikutnya } \\
\text { setelah kata } \\
\text { kunci }\end{array}$ \\
\hline ISBN & $\begin{array}{ll}- & \text { ISBN } \\
- & \text { isbn }\end{array}$ & $\begin{array}{l}\text { mengambil kata } \\
\text { setelah kata } \\
\text { kunci "ISBN" } \\
\text { atau "isbn" } \\
\text { maka diambil } \\
\text { sebagai ISBN } \\
\text { novel. }\end{array}$ \\
\hline E-ISBN & $\begin{array}{ll}- & \text { E-ISBN } \\
- & \text { e-isbn }\end{array}$ & $\begin{array}{l}\text { - mengambil kata } \\
\text { setelah kata } \\
\text { kunci "E-ISBN" } \\
\text { atau "EISBN" } \\
\text { atau "e-isbn" } \\
\text { maka diambil } \\
\text { sebai E-ISBN } \\
\text { novel. }\end{array}$ \\
\hline
\end{tabular}

\subsection{Ekstraksi Judul}

Proses ekstraksi informasi (Information Extraction atau IE) adalah sebuah proses untuk mendapatkan informasi inti dari suatu dokumen tidak terstruktur menjadi dokumen terstruktur yang mudah dikenali. Adapun data yang terstruktur adalah data yang telah terorganisir sehingga mudah dalam suatu pencarian data sedangkan tidak terstruktur adalah data yang belum terorganisir [5].

Proses ekstraksi judul berdasarkan pengamatan data novel maka diambil kesimpulan bahwa dalam pengambilan judul novel, proses yang akan dilakukan pada penelitian ekstraksi informasi pada novel menerapkan rule-base untuk mengetahui judul dari sebuah novel adalah dengan aturan bahwa yang baris pertama dari data dokumen adalah judul dari novel dapat dilihat pada gambar 3 .

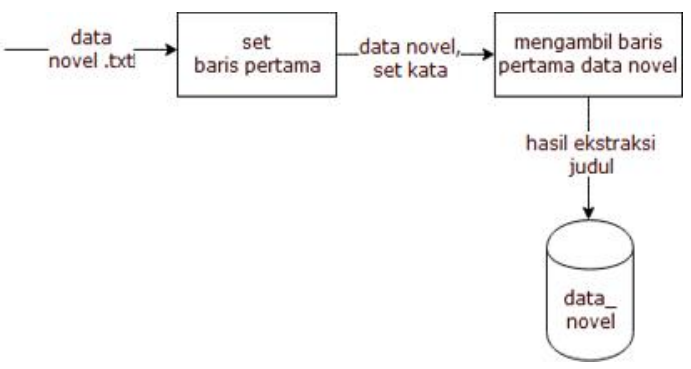

Gambar 3. Ekstraksi Judul

Aturan yang diambil untuk ekstraksi informasi judul adalah menggunakan aturan yaitu mengambil baris pertama dari data novel sebagai judul. Apa yang ada di baris pertama data novel adalah judul. Contoh ekstraksi judul di lihat pada tabel 2. 
Tabel 2. Ekstraksi Judul

\begin{tabular}{|l|}
\hline \multicolumn{1}{|c|}{ Masukan } \\
\hline PRIBADI DAN MARTABAT BUYA HAMKA \\
Penulis; H. Rusydi Hamka \\
Copyright @ H. Rusydi Hamka , 2016 \\
All rights reserve d \\
Hat cipta dilindung undang-undang \\
Penyunting : Laura Ariestiyanty \\
Penyelaras Aksara: Meni Suryani \& Lya Astika \\
Penata Akssra : Abdul Waha b \\
llustrasi Sampul : Robbi Gandaman a \\
Perancan g Sampul: AS. Zuhri \\
Digitalisasi: EHizaTittti \\
Diterbitkan oleh Penerbit Noura (PT Mizan \\
Publika) \\
Anggota IKAPI \\
Jl. Jagakarsa Raya, No. 40 Rt 007/Rw 004 \\
Jagakarsa, Jakarta Selatan 12620 \\
Tdp, 021-788S0556, Fab . 021-78\&S056 3 \\
E-mail: redaksi@ frnoura.mizan.com \\
http://nourabooks.co.id \\
ISBN 973-602-385-240-6 \\
E-ISBN: 97S-602-385-246-8 \\
Ebook ini didistribusikan oleh: Mizan Digital \\
Publishing \\
Jl. Jagakarsa Raya No. 40 Jakarta Selatan - 12620 \\
Phone.: +62-21-7864547 (Hunting) \\
Fax.: +62-21-7864272 \\
email: mizandigitalpublishing @ mizan.com \\
Bahan dengan hak cipta \\
\hline \multicolumn{1}{c|}{ Keluaran } \\
\hline PRIBADI DAN MARTABAT BUYA HAMKA \\
\hline
\end{tabular}

\subsection{Ekstraksi Penulis}

Proses ekstraksi penulis berdasarkan pengamatan data novel menerapkan rule-base pada ekstraksi penulis dilihat pada gamber 4 .

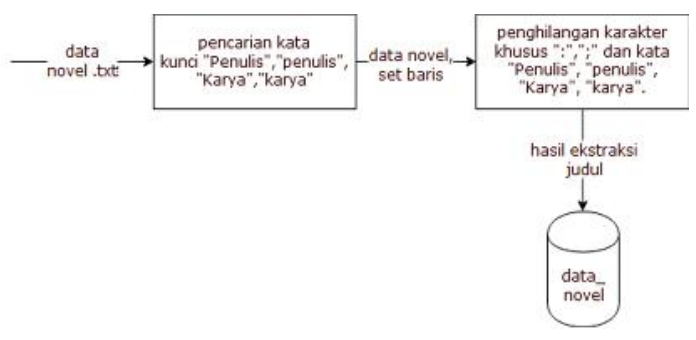

Gambar 4. Ekstraksi Penulis

Aturan yang diambil untuk ekstraksi informasi penulis adalah :

1. Jika kata "Penulis atau "penulis" atau "Karya" atau "karya" maka simpan baris tersebut

2. Jika kata setelah kata kunci kosong maka diambil baris berikutnya setelah kata kunci "Penulis atau "penulis" atau "Karya" atau "karya"

3. Setelah simpan baris maka baris akan di preprocessing penghilangan karakter khusus yang ada pada baris tersebut.

Berikut contoh ekstraksi penulis di lihat pada tabel 3 .
Tabel 3. Ekstraksi Penulis Masukan

PRIBADI DAN MARTABAT BUYA HAMKA

Penulis; H. Rusydi Hamka

Copyright $@$ C H. Rusydi Hamka, 2016

All rights reserve d

Hat cipta dilindung undang-undang

Penyunting : Laura Ariestiyanty

Penyelaras Aksara: Meni Suryani \& Lya Astika

Penata Akssra : Abdul Waha b

llustrasi Sampul : Robbi Gandaman a

Perancan g Sampul: AS. Zuhri

Digitalisasi: EHizaTittti

Diterbitkan oleh Penerbit Noura (PT Mizan

Publika)

Anggota IKAPI

Jl. Jagakarsa Raya, No. 40 Rt 007/Rw 004

Jagakarsa , Jakarta Selatan 12620

Tdp , 021-788S0556 , Fab . 021-78\&S056 3

E-mail: redaksi@frnoura.mizan.com

http://nourabooks.co.id

ISBN 973-602-385-240-6

E-ISBN: 97S-602-385-246-8

Ebook ini didistribusikan oleh: Mizan Digital Publishing

Jl. Jagakarsa Raya No. 40 Jakarta Selatan - 12620

Phone.: +62-21-7864547 (Hunting)

Fax.: +62-21-7864272

email: mizandigitalpublishing@mizan.com

Bahan dengan hak cipta

\begin{tabular}{l}
\hline Keluaran \\
H. Rusydi Hamka
\end{tabular}

\subsection{Ekstraksi Tahun Terbit Atau Terbitan \\ Pertama}

Proses ekstraksi tahun terbit atau terbitan pertama berdasarkan pengamatan data novel menerapkan rule-base pada ekstraksi tahun terbit dilihat pada gambar 5 .

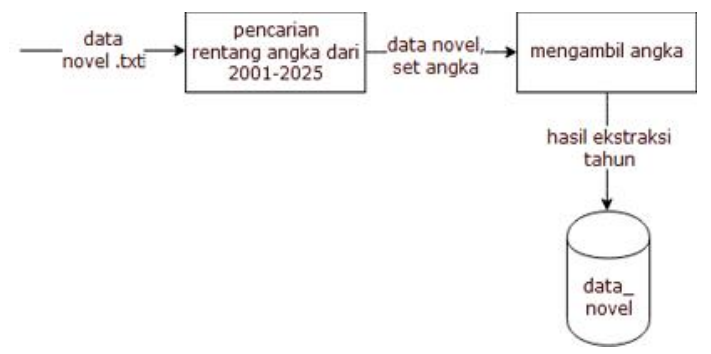

Gambar 5. Ekstraksi Tahun Terbit

Aturan yang diambil untuk ekstraksi informasi tahun terbit atau terbitan pertama adalah

1. Mengambil rentang angka 2001 - 2025 maka ambil sebagai tahun terbit

2. mengambil angka yang paling awal ditemukan.

Berikut contoh ekstraksi tahun terbit di lihat pada tabel 4. 
Tabel 4. Ekstraksi Tahun Terbit

\begin{tabular}{|l|}
\hline \multicolumn{1}{|c|}{ Masukan } \\
\hline PRIBADI DAN MARTABAT BUYA HAMKA \\
Penulis; H. Rusydi Hamka \\
Copyright @ H. Rusydi Hamka, 2016 \\
All rights reserve d \\
Hat cipta dilindung undang-undang \\
Penyunting : Laura Ariestiyanty \\
Penyelaras Aksara: Meni Suryani \& Lya Astika \\
Penata Akssra : Abdul Waha b \\
llustrasi Sampul : Robbi Gandaman a \\
Perancan g Sampul: AS. Zuhri \\
Digitalisasi: EHizaTittti \\
Diterbitkan oleh Penerbit Noura (PT Mizan \\
Publika) \\
Anggota IKAPI \\
Jl. Jagakarsa Raya, No. 40 Rt 007/Rw 004 \\
Jagakarsa, Jakarta Selatan 12620 \\
Tdp, 021-788S0556, Fab . 021-78\&S056 3 \\
E-mail: redaksi@ @rnoura.mizan.com \\
http://nourabooks.co.id \\
ISBN 973-602-385-240-6 \\
E-ISBN: 97S-602-385-246-8 \\
Ebook ini didistribusikan oleh: Mizan Digital \\
Publishing \\
Jl. Jagakarsa Raya No. 40 Jakarta Selatan - 12620 \\
Phone.: +62-21-7864547 (Hunting) \\
Fax.: +62-21-7864272 \\
email: mizandigitalpublishing@mizan.com \\
Bahan dengan hak cipta \\
\hline \multicolumn{1}{|c|}{ Keluaran } \\
\hline 2016 \\
\hline
\end{tabular}

\subsection{Ekstraksi Penerbit}

Proses ekstraksi penerbit berdasarkan pengamatan data novel menerapkan rule-base pada ekstraksi penerbit dilihat pada gamber 6 .

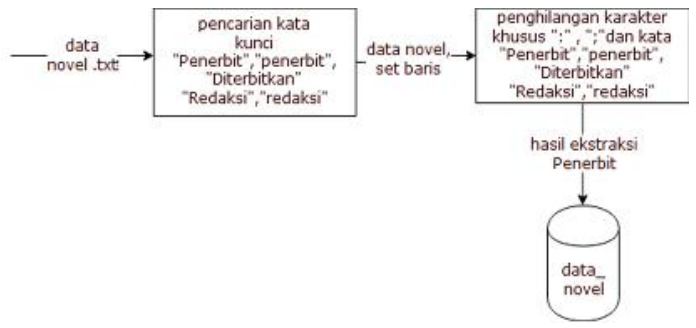

Gambar 6. Ekstraksi Penerbit

Aturan yang diambil untuk ekstraksi informasi penerbit adalah

1. Menggunakan kata kunci yaitu Jika kata "Penerbit" atau kata "penerbit" atau kata "Diterbitkan oleh" atau kata "redaksi" atau kata "Redaksi" atau maka simpan baris yang terdapat kata kunci

2. Jika kata setelah kata kunci kosong maka diambil baris berikutnya setelah kata kunci

3. menghilangkan karakter khusus pada baris kata kunci
Berikut contoh ekstraksi penerbit di lihat pada tabel 5 .

\section{Tabel 5. Ekstraksi Penerbit}

\begin{tabular}{|l|}
\hline \multicolumn{1}{|c|}{ Masukan } \\
\hline PRIBADI DAN MARTABAT BUYA HAMKA \\
Penulis; H. Rusydi Hamka \\
Copyright @ H. Rusydi Hamka, 2016 \\
All rights reserve d \\
Hat cipta dilindung undang-undang \\
Penyunting : Laura Ariestiyanty \\
Penyelaras Aksara: Meni Suryani \& Lya Astika \\
Penata Akssra : Abdul Waha b \\
llustrasi Sampul : Robbi Gandaman a \\
Perancan g Sampul: AS. Zuhri \\
Digitalisasi: EHizaTittti \\
Diterbitkan oleh Penerbit Noura (PT Mizan \\
Publika) \\
Anggota IKAPI \\
Jl. Jagakarsa Raya, No. 40 Rt 007/Rw 004 \\
Jagakarsa, Jakarta Selatan 12620 \\
Tdp, 021-788S0556, Fab . 021-78\&S056 3 \\
E-mail: redaksi@ frnoura.mizan.com \\
http://nourabooks.co.id \\
ISBN 973-602-385-240-6 \\
E-ISBN: 97S-602-385-246-8 \\
Ebook ini didistribusikan oleh: Mizan Digital \\
Publishing \\
Jl. Jagakarsa Raya No. 40 Jakarta Selatan - 12620 \\
Phone.: +62-21-7864547 (Hunting) \\
Fax.: +62-21-7864272 \\
email: mizandigitalpublishing@mizan.com \\
Bahan dengan hak cipta \\
\hline \multicolumn{1}{c|}{ Keluaran } \\
\hline Noura (PT Mizan Publika) \\
\hline
\end{tabular}

\subsection{Ekstraksi ISBN}

Proses ekstraksi ISBN berdasarkan pengamatan data novel menerapkan rule-base pada ekstraksi ISBN dilihat pada gamber 7 .

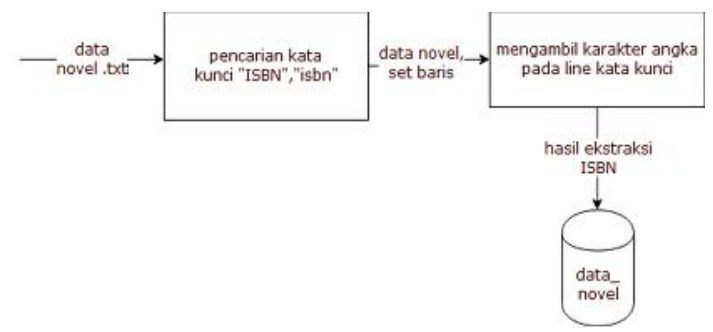

Gambar 7. Ekstraksi ISBN

Aturan yang diambil untuk ekstraksi informasi ISBN adalah :

1. Jika kata "ISBN" atau "isbn" maka simpan baris yang terdapat kata kunci

2. Mengambil karakter angka pada baris kata kunci. Berikut contoh ekstraksi ISBN di lihat pada tabel 
Tabel 6. Ekstraksi ISBN

\begin{tabular}{|l|}
\hline \multicolumn{1}{|c|}{ Masukan } \\
\hline PRIBADI DAN MARTABAT BUYA HAMKA \\
Penulis; H. Rusydi Hamka \\
Copyright @ H. Rusydi Hamka, 2016 \\
All rights reserve d \\
Hat cipta dilindung undang-undang \\
Penyunting : Laura Ariestiyanty \\
Penyelaras Aksara: Meni Suryani \& Lya Astika \\
Penata Akssra : Abdul Waha b \\
llustrasi Sampul : Robbi Gandaman a \\
Perancan g Sampul: AS. Zuhri \\
Digitalisasi: EHizaTittti \\
Diterbitkan oleh Penerbit Noura (PT Mizan \\
Publika) \\
Anggota IKAPI \\
Jl. Jagakarsa Raya, No. 40 Rt 007/Rw 004 \\
Jagakarsa, Jakarta Selatan 12620 \\
Tdp, 021-788S0556, Fab . 021-78\&S056 3 \\
E-mail: redaksi @ frnoura.mizan.com \\
http://nourabooks.co.id \\
ISBN 973-602-385-240-6 \\
E-ISBN: 97S-602-385-246-8 \\
Ebook ini didistribusikan oleh: Mizan Digital \\
Publishing \\
Jl. Jagakarsa Raya No. 40 Jakarta Selatan - 12620 \\
Phone.: +62-21-7864547 (Hunting) \\
Fax.: +62-21-7864272 \\
email: mizandigitalpublishing@ @mizan.com \\
Bahan dengan hak cipta \\
\hline \multicolumn{1}{c|}{ Keluaran } \\
\hline 973-602-385-240-6 \\
\hline
\end{tabular}

\subsection{Ekstraksi E-ISBN}

Proses ekstraksi E-ISBN berdasarkan pengamatan data novel menerapkan rule-base pada ekstraksi E-ISBN dilihat pada gamber 8

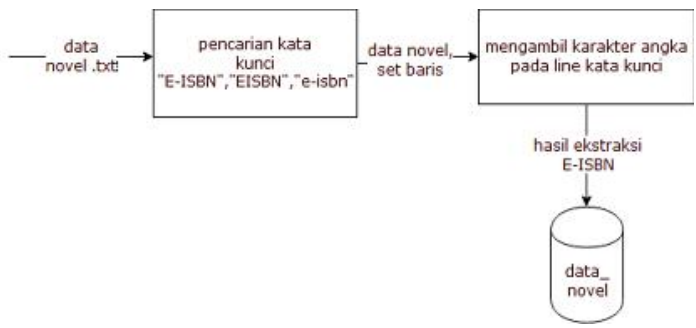

Gambar 8. Ekstraksi E-ISBN

Aturan yang diambil untuk ekstraksi informasi E-ISBN adalah

1. Jika kata "E-ISBN" atau "EISBN" atau "e-isbn" maka simpan baris yang terdapat kata kunci

2. mengambil karakter angka pada line kata kunci

Berikut contoh ekstraksi E-ISBN di lihat pada tabel 7.

\section{Tabel 7. Ekstraksi E-ISBN}

\begin{tabular}{|l|}
\hline \multicolumn{1}{|c|}{ Masukan } \\
\hline PRIBADI DAN MARTABAT BUYA HAMKA \\
Penulis; H. Rusydi Hamka \\
Copyright @ H. Rusydi Hamka, 2016 \\
All rights reserve d \\
Hat cipta dilindung undang-undang \\
Penyunting : Laura Ariestiyanty \\
Penyelaras Aksara: Meni Suryani \& Lya Astika \\
Penata Akssra : Abdul Waha b \\
llustrasi Sampul : Robbi Gandaman a \\
Perancan g Sampul: AS. Zuhri \\
Digitalisasi: EHizaTittti \\
Diterbitkan oleh Penerbit Noura (PT Mizan \\
Publika) \\
Anggota IKAPI \\
Jl. Jagakarsa Raya, No. 40 Rt 007/Rw 004 \\
Jagakarsa, Jakarta Selatan 12620 \\
Tdp, 021-788S0556, Fab . 021-78\&S056 3 \\
E-mail: redaksi @ frnoura.mizan.com \\
http://nourabooks.co.id \\
ISBN 973-602-385-240-6 \\
E-ISBN: 97S-602-385-246-8 \\
Ebook ini didistribusikan oleh: Mizan Digital \\
Publishing \\
Jl. Jagakarsa Raya No. 40 Jakarta Selatan - 12620 \\
Phone.: +62-21-7864547 (Hunting) \\
Fax.: +62-21-7864272 \\
email: mizandigitalpublishing@ @izan.com \\
Bahan dengan hak cipta \\
\hline \multicolumn{1}{|c|}{ Keluaran } \\
\hline 97S-602-385-246-8 \\
\hline
\end{tabular}

\subsection{Pengujian Ekstraksi Informasi}

Pengujian ekstraksi merupakan tahap yang memiliki tujuan untuk mengetahui performa dari metode rulebase yang digunakan pada sistem yang dibangun. menghasilkan ekstraksi yang diinginkan baik judul, penulis, tahun terbit, penerbit, isbn, dan eisbn. Pengujian dilakukan dengan 50 data set.

\section{a. Hasil Perbandingan Ekstraksi Informasi}

Ekstraksi informasi perbandingan dokumen dengan data sistem pada data novel yaitu judul, penulis, tahun terbit atau terbitan pertama, penerbit, ISBN dan E-ISBN. Hasilnya dapat dilihat pada tabel 8.

\section{Tabel 8. Hasil Ekstraksi}

\begin{tabular}{|l|l|l|l|}
\hline No & $\begin{array}{l}\text { Judul novel } \\
\text { setelah } \\
\text { konversi }\end{array}$ & \multicolumn{1}{|c|}{$\begin{array}{c}\text { Hasil } \\
\text { Ekstraksi }\end{array}$} & $\begin{array}{l}\text { Kesim } \\
\text { pulan }\end{array}$ \\
\hline 1 & $\begin{array}{l}\text { Pribadi dan } \\
\text { martabat } \\
\text { buya hamka }\end{array}$ & $\begin{array}{l}\text { Pribadi dan } \\
\text { martabat } \\
\text { buya hamka }\end{array}$ & Sesuai \\
\hline 2 & $\begin{array}{l}\text { Happily } \\
\text { Ever After }\end{array}$ & $\begin{array}{l}\text { Happily } \\
\text { Ever After }\end{array}$ & Sesuai \\
\hline 3 & $\begin{array}{l}\text { J0mbl0: } \\
\text { Sebuah } \\
\text { Komedi }\end{array}$ & $\begin{array}{l}\text { J0mbl0: } \\
\text { Sebuah } \\
\text { Komedi }\end{array}$ & Sesuai \\
\hline
\end{tabular}


Jurnal Ilmiah Komputer dan Informatika (KOMPUTA)

Vol. 8, No. 1, Maret 2019, ISSN : 2089-9033, eISSN : 2715-7849

\begin{tabular}{|c|c|c|c|}
\hline No & $\begin{array}{c}\text { Judul novel } \\
\text { setelah } \\
\text { konversi } \\
\end{array}$ & $\begin{array}{c}\text { Hasil } \\
\text { Ekstraksi }\end{array}$ & $\begin{array}{l}\text { Kesim } \\
\text { pulan }\end{array}$ \\
\hline & Cinta & Cinta & \\
\hline 4 & $\begin{array}{l}\text { LO, } \\
\text { TUNANGA } \\
\text { N GU!!! }\end{array}$ & $\begin{array}{l}\text { LO, } \\
\text { TUNANGA } \\
\text { N GU!!! }\end{array}$ & Sesuai \\
\hline 5 & P0sesTF & P0sesTF & Sesuai \\
\hline 6 & Memmkimii & Memmkimii & Sesuai \\
\hline 7 & $\begin{array}{l}\text { Move On } \\
\text { \#Crazyl,ove }\end{array}$ & $\begin{array}{l}\text { Move On } \\
\text { \#Crazyl,ove }\end{array}$ & Sesuai \\
\hline 8 & $\begin{array}{l}\text { My } \\
\text { Favour i+e } \\
\text { Dis+ } \\
\text { rc1c+ion }\end{array}$ & $\begin{array}{l}\text { My } \\
\text { Favour i+e } \\
\text { Dis+ } \\
\text { rc1c+ion }\end{array}$ & Sesuai \\
\hline 9 & $\begin{array}{l}\text { MIMPI } \\
\text { BAYANG } \\
\text { JINGGA }\end{array}$ & $\begin{array}{l}\text { MIMPI } \\
\text { BAYANG } \\
\text { JINGGA }\end{array}$ & Sesuai \\
\hline 10 & $\begin{array}{l}\text { Jctuh Cinta } \\
\text { Diam-Diam } \\
\# 2\end{array}$ & $\begin{array}{l}\text { Jctuh Cinta } \\
\text { Diam-Diam } \\
\# 2\end{array}$ & Sesuai \\
\hline 11 & $\begin{array}{l}\text { Setelah } \\
\text { Kamu Pergi }\end{array}$ & $\begin{array}{l}\text { Setelah } \\
\text { Kamu Pergi }\end{array}$ & Sesuai \\
\hline 12 & Spy in Love & Spy in Love & Sesuai \\
\hline 13 & $\begin{array}{l}\text { LDR } \\
\text { \#CrazyLove }\end{array}$ & $\begin{array}{l}\text { LDR } \\
\text { \#CrazyLove }\end{array}$ & Sesuai \\
\hline 14 & $\begin{array}{l}\text { Married in } \\
\text { Trouble }\end{array}$ & $\begin{array}{l}\text { Married in } \\
\text { Trouble }\end{array}$ & Sesuai \\
\hline 15 & $\begin{array}{l}\text { SWU } \\
\text { BERSANH } \\
\text { Wm }\end{array}$ & $\begin{array}{l}\text { SWU } \\
\text { BERSANH } \\
\text { Wm }\end{array}$ & Sesuai \\
\hline 16 & $\begin{array}{l}\text { ISTRIKU } \\
\text { SERIBU }\end{array}$ & $\begin{array}{l}\text { ISTRIKU } \\
\text { SERIBU }\end{array}$ & Sesuai \\
\hline 17 & $\begin{array}{l}\text { QMTA } \\
\text { 5goAToIAu } \\
\text { QuI }\end{array}$ & $\begin{array}{l}\text { QMTA } \\
\text { 5goAToIAu } \\
\text { QuI }\end{array}$ & Sesuai \\
\hline 18 & $\begin{array}{l}\text { Manusia } \\
\text { Setengah } \\
\text { Salmon }\end{array}$ & $\begin{array}{l}\text { Manusia } \\
\text { Setengah } \\
\text { Salmon }\end{array}$ & Sesuai \\
\hline 19 & $\begin{array}{l}\text { FREYA } \\
\text { VALIKRYE }\end{array}$ & $\begin{array}{l}\text { FREYA } \\
\text { VALIKRYE }\end{array}$ & Sesuai \\
\hline 20 & $\begin{array}{l}\text { MUHAMM } \\
\text { AD: Lelaki } \\
\text { Penggengga } \\
\text { m Hujan }\end{array}$ & $\begin{array}{l}\text { MUHAMM } \\
\text { AD: Lelaki } \\
\text { Penggengga } \\
\text { m Hujan }\end{array}$ & Sesuai \\
\hline 21 & $\begin{array}{l}\text { SANG } \\
\text { PEMIMPI }\end{array}$ & $\begin{array}{l}\text { SANG } \\
\text { PEMIMPI }\end{array}$ & Sesuai \\
\hline 22 & $\begin{array}{l}\text { Kambingjant } \\
\text { an }\end{array}$ & $\begin{array}{l}\text { Kambingjant } \\
\text { an }\end{array}$ & Sesuai \\
\hline 23 & $\begin{array}{l}7 \\
\text { '"Yll ' vi'R } \\
@_{\text {@ _ !wW }} \\
\text { Sclvlm }\end{array}$ & $\begin{array}{l}7 \\
\text { '”Yll ' vi'R } \\
\text { @_ !wW } \\
\text { Sclvlm }\end{array}$ & Sesuai \\
\hline 24 & $\begin{array}{l}\text { Look! I'm } \\
\text { On Fire }\end{array}$ & $\begin{array}{l}\text { Look! I'm } \\
\text { On Fire }\end{array}$ & Sesuai \\
\hline 25 & $\begin{array}{l}\text { Di } \\
\text { Peia/45 } 6\end{array}$ & $\begin{array}{l}\text { Di } \\
\text { Peia/45 } 6\end{array}$ & Sesuai \\
\hline 26 & $\begin{array}{l}\text { GBLANDA } \\
\text { NGAN DI }\end{array}$ & $\begin{array}{l}\text { GBLANDA } \\
\text { NGAN DI }\end{array}$ & esuai \\
\hline
\end{tabular}

\begin{tabular}{|c|c|c|c|}
\hline No & $\begin{array}{c}\text { Judul novel } \\
\text { setelah } \\
\text { konversi }\end{array}$ & $\begin{array}{c}\text { Hasil } \\
\text { Ekstraksi }\end{array}$ & $\begin{array}{l}\text { Kesim } \\
\text { pulan }\end{array}$ \\
\hline & $\begin{array}{l}\text { KAMPUNG } \\
\text { SENDIRI }\end{array}$ & $\begin{array}{l}\text { KAMPUNG } \\
\text { SENDIRI }\end{array}$ & \\
\hline 27 & $\begin{array}{l}\text { Marrmgeabfi } \\
\text { c }\end{array}$ & $\begin{array}{l}\text { Marrmgeabfi } \\
\text { c }\end{array}$ & Sesuai \\
\hline 28 & $\begin{array}{l}\text { Let's Break } \\
\text { Up }\end{array}$ & $\begin{array}{l}\text { Let's Break } \\
\text { Up }\end{array}$ & Sesuai \\
\hline 29 & $\begin{array}{l}777 \mathrm{e}, 7 \phi / \mathrm{La} / \\
2, ;\end{array}$ & $\begin{array}{l}777 \mathrm{e}, 7 \phi / \mathrm{La} / \\
2, ;\end{array}$ & Sesuai \\
\hline 30 & $\begin{array}{l}\text { HERE. } \\
\text { AFTER }\end{array}$ & $\begin{array}{l}\text { HERE. } \\
\text { AFTER }\end{array}$ & Sesuai \\
\hline 31 & $\begin{array}{l}\text { Cat Lover's } \\
\text { Book }\end{array}$ & $\begin{array}{l}\text { Cat Lover's } \\
\text { Book }\end{array}$ & Sesuai \\
\hline 32 & $\begin{array}{l}\text { Memories to } \\
\text { Forget }\end{array}$ & $\begin{array}{l}\text { Memories to } \\
\text { Forget }\end{array}$ & Sesuai \\
\hline 33 & $\begin{array}{l}\text { When Love } \\
\text { Walked In }\end{array}$ & $\begin{array}{l}\text { When Love } \\
\text { Walked In }\end{array}$ & Sesuai \\
\hline 34 & $\begin{array}{l}\text { Apa Pun } \\
\text { Qdain -I- } \\
\text { l'uJ',an }\end{array}$ & $\begin{array}{l}\text { Apa Pun } \\
\text { Qdain -I- } \\
\text { l'uJ',an }\end{array}$ & Sesuai \\
\hline 35 & $\begin{array}{l}\text { ?M *\% @ } \\
>-\end{array}$ & $\begin{array}{l}\text { ?M *\% @ } \\
>-\end{array}$ & Sesuai \\
\hline 36 & $\begin{array}{l}\text { SOMEWHE } \\
\text { RE ONLY } \\
\text { WE KNOW } \\
\end{array}$ & $\begin{array}{l}\text { SOMEWHE } \\
\text { RE ONLY } \\
\text { WE KNOW } \\
\end{array}$ & Sesuai \\
\hline 37 & fifimclwle & fifimclwle & Sesuai \\
\hline 38 & $\begin{array}{l}\text { Unforgettabl } \\
\text { e }\end{array}$ & $\begin{array}{l}\text { Unforgettabl } \\
\text { e }\end{array}$ & Sesuai \\
\hline 39 & $\begin{array}{l}\text { LAST } \\
\text { FOREVER }\end{array}$ & $\begin{array}{l}\text { LAST } \\
\text { FOREVER }\end{array}$ & Sesuai \\
\hline 40 & $\begin{array}{l}\text { Goodbye } \\
\text { Happiness }\end{array}$ & $\begin{array}{l}\text { Goodbye } \\
\text { Happiness }\end{array}$ & Sesuai \\
\hline 41 & $\begin{array}{l}\text { Péllow } \\
\text { TQZK }\end{array}$ & $\begin{array}{l}\text { Péllow } \\
\text { TQZK }\end{array}$ & Sesuai \\
\hline 42 & $\begin{array}{l}\text { Ocean } \\
\text { Melodq }\end{array}$ & $\begin{array}{l}\text { Ocean } \\
\text { Melodq }\end{array}$ & Sesuai \\
\hline 43 & $\begin{array}{l}\text { Catatan } \\
\text { Ayah } \\
\text { tentang } \\
\text { Cintanya } \\
\text { kepada lbu }\end{array}$ & $\begin{array}{l}\text { Catatan } \\
\text { Ayah } \\
\text { tentang } \\
\text { Cintanya } \\
\text { kepada lbu }\end{array}$ & Sesuai \\
\hline 44 & DROP OUT & DROP OUT & Sesuai \\
\hline 45 & Siap Kuliah & Siap Kuliah & Sesuai \\
\hline 46 & $\begin{array}{l}\text { QEWNG } \\
|<5 \mathrm{~A}| \sim(\end{array}$ & $\begin{array}{l}\text { QEWNG } \\
|<5 \mathrm{~A}| \sim(\end{array}$ & Sesuai \\
\hline 47 & FEEL REAL & FEEL REAL & Sesuai \\
\hline 48 & $4 * ?$ & $4 * ?$ & Sesuai \\
\hline 49 & $\begin{array}{l}\text { Melampaui } \\
\text { Mimpi }\end{array}$ & $\begin{array}{l}\text { Melampaui } \\
\text { Mimpi }\end{array}$ & Sesuai \\
\hline 50 & Quin Affair & Quin Affair & Sesuai \\
\hline
\end{tabular}

\section{b. Pengujian Akurasi}

Pengujian akurasi ini dilakukan untuk mengetahui akurasi dalam mengidentifikasi hasil ekstraksi informasi. Tingkat akurasi diperoleh dengan perhitungan berikut 
- $\quad$ Banyak data uji : 50

$$
\begin{aligned}
& \text { - } A=\frac{p}{B} \quad \begin{array}{ll}
D & B \\
\hline B & u
\end{array} 100 \% \\
& =100 \% \\
& =\frac{5}{5} \times 100 \%
\end{aligned}
$$

\section{PENUTUP}

Kesimpulan yang didapat dari penelitian yang telah dilakukan diketahui bahwa dari 50 data novel berhasil di ekstraksi sebanyak 100\% yaitu judul, pengarang, tahun terbit, penerbit, ISBN dan E-ISBN dengan ketentuan berdasarkan hasil konversi, meskipun terdapat kesalahan hasil konversi judul karena dalam dataset terdapat jenis font yang sulit dikenali oleh sistem. Berdasarkan hal tersebut di simpulkan bahwa metode rule-base untuk penelitian ekstraksi informasi pada teks novel sangat baik

Berdasarkan hasil penelitian yang telah dilakukan, masalah yang muncul pada penelitian ini adanya hasil konversi data novel ke format .txt. Konversi dilakukan menggunakan aplikasi FreeOCR masih terdapat kesalahan pada judul novel yang tidak sesuai dengan data asli novel. Saat melakukan konversi data format JPG ke format .txt, terdapat font yang tidak dapat dikenali oleh sistem freeOCR sehingga menghasilkan konversi yang berbeda dengan data asli. Adapun saran untuk kajian lebih lanjut sebagai berikut.

1. Penambahan metode atau algoritma pendeteksian kesalahan teks pada dokumen bahasa indonesia.

2. Untuk pengembangan selanjutnya, menambahkan lebih banyak data novel untuk memperkaya aturan sehingga mendukung penanganan variasi data yang berbeda.

\section{DAFTAR PUSTAKA}

[1] Susilawati Erna. Analisis Pengaruh kepribadian dan Harga terhadap Impulse Buying pada Produk Novel di Toko Buku Bandung Book Center Wilayah Bandung. Jurnal Unikom. 2016: $1-8$.

[2] Jiang Jing. Information Extraction from Text. Spinger Science and Business Media. 2012.

[3] Peleato Ramon Aragues, Jean-Cedric Chappelier, Martin Rajman. Using Imformation Extraction to Classify Newspapers Advertisements. Journal International on Statistical Analysis of Textual Data (JADT). 2000 .

[4] Riaddy Aditya Iftikar, Yuliant Sibaroni, Annisa Aditsania. Ekstraksi Informasi pada Makalah Ilmiah dengan Pendekatan Supervised Learning. Jurnal Program Studi Ilmu Komputasi, Fakultas Informatika, Universitas Telkom. 2016: 1-7.
[5] Ismaya Agny. Algoritma Ekstraksi Informasi Berbasis Aturan. Jurnal Nasional Teknik Elektor dan Teknik Informasi (JNTETI). 2014; 3(4): 242-247

[6] M. Habibi. Ekstraksi Informasi Dengan Metode Rule-Based Untuk Evaluasi Pemahaman Fisika Kinematika. Journal Informatika. 2016.

[7] HS Karibun M. Penerapan Metode Rule-Based Dengan Unsupervised Learning Untuk Pelabelan Dokumen Berbahasa Indonesia. Journal Informatika. 2005: 1-10.

[8] Al Amin Imam Husni, Suhartono. Sistem Pakar Mendeteksi Kerusakan Rambut Menggunakan Basis Aturan (Rule Base Reasoning) dengan Metode Forward Chaining. Jurnal Sistem Informasi Bisnis. 2012; 3: 134-138.

[9] Galih R Sandhika, Erik, Muhammad Lukman Hakim. Penerapan Teknik OCR (Optical Character Recognition) pada Aplikasi Terjemah Kitab Fiqih Safinah An-Naja menggunakan Readiris. Jurusan Teknik Informatika Universitas Pasundan Bandung. 2014.

[10] Hulth Anette, Beata B. Megyesi. A Study on Automatically Extracted Keywords in Text Categorization. Association for Computational Linguistics. 2006: 537-544. 